\title{
Hybridity in Willa Cather's Death Comes for the Archbishop and Shadows on the Rock
}

\author{
Maryam Heydari Fard (Corresponding author) \\ English Department, Faculty of Foreign Languages, University of Isfahan, Isfahan, IRAN \\ E-mail:m.heydari1989@gmail.com \\ Hossein Pirnajmuddin \\ English Department, Faculty of Foreign Languages, University of Isfahan, Isfahan, IRAN \\ E-mail: pirnajmuddin@fgn.ui.ac.ir
}

Doi:10.7575/aiac.alls.v.6n.1p.81

Received: 19/09/2014

URL: http://dx.doi.org/10.7575/aiac.alls.v.6n.1p.81

Accepted: 22/11/2014

\begin{abstract}
Willa Cather wrote Death Comes for the Archbishop and Shadows on the Rock based on the missionary life of Europeans in Quebec and New Mexico. In both novels she depicts a different type of colonizer-colonized relationship. The colonizers arrive with their stereotypical views about the natives to purportedly civilize them. But later, through their interaction with the natives, their superior, patronizing attitude gradually changes, so that, the boundary between the colonizer and the colonized becomes blurred. Contrary to their presuppositions about natives and also the longestablished colonial attitude, the missionaries in these two novels treat the natives sympathetically and in some cases equally. Using Homi Bhabha's theory of hybridity, this essay attempts to analyze these two novels in terms of the depiction of cultural relation/interaction.
\end{abstract}

Keywords: Willa Cather, Death Comes for the Archbishop, Shadows on the Rock, Colonialism, Cultural Hybridity

\section{Introduction}

Willa Cather's two late sequential novels, Death comes for the Archbishop (1927) and Shadows on the Rock (1931), are historical fictions. Cather focuses on the lives of two groups of missionaries in New Mexico and Quebec in these novels. She tries hard and reads widely to achieve some kind of historical accuracy and authenticity in them. After reading The Life of the Right Reverend Joseph P. Machebeuf, by William Joseph Hewlett, Cather becomes inspired by the thoughts, feelings and experiences of pioneer priests and missionaries in New Mexico. Some of the main characters are based on real historical personages figuring either under their real names or fictional ones. She brings historical characters sometimes with changing their names into her fictional characters; for instance, in Death Comes for the Archbishop, Father Jean Marie Latour and Father Joseph Vaillant were changed out of actual names of Father Lamy and Father Machebeuf. Even in some cases, without changing the real historical characters names, she uses them in her novels such as Father Martinez in Death Comes for the Archbishop and Bishop Lavel and Count de Frontenac in Shadows on the Rock (Danker, 2000, p 37). Based on these two novels' solid historical background, most of the written reviews and researches on them focus mainly on their historical authenticity. Danker (2000) in her notable article which focused on historical baseness of novels argues that what Cather collected out of "historical accounts, church records, newspaper files and family stories about the French Canadians" reveal the historical bases of the novels (p. 37). But this essay attempts to shed light to these novels from a different perspective; a postcolonial one, the aspect that remained in the shadow of historical power of these novels. This study's aim is to address the way Cather envisions and registers cultural hybridity.

In these novels, Cather experimented with a new kind of form, a new genre that made most of the reviewers to begin their reviews by this sentence, "This book is hard to classify"(Cather, 1949, p. 12). Guy Reynolds notes that a number of earlier scholars grappled with the novels in order to classify them in various ways "as history, biography, or fiction" (as cited in Park, 2006, p. 13). Apart from their unclassifiable genre, Cather's latter novels lack the conventional plot form, and in the eyes of their readers, because of their "plotlessness and episodic construction, to be barely novels at all" (Reynolds, 2005, p. ix). They develop through chronological episodes, so that there is no stable ground for recognizing the characters. Notwithstanding the novels' episodic structure, Cather relies on incidents to reveal characters (Daiches, 1951, p. 129). By analyzing these incidents, dialogues and reactions, this essay attempts to probe the modality of the formation of these characters. The assumption is that missionaries -- colonizers indeed -- in both of these novels do not wholly behave like former colonizers. They start their mission with pre-established, fixed opinions about the natives but their attitude changes gradually and turn into a more understanding, accommodating one. Focusing on the characters' actions and reactions and the colonizer and colonized relationship, the objective is to examine the applicability of Homi Bhabha's theory of hybridity to analysis of the process of transformation of characters. 


\section{Discussion}

The word 'hybrid', the Oxford English Dictionary explains, comes to modern languages from the Latin ibrida, and refers to the "offspring of a tame sow and a wild boar". The definitional narrative then calmly moves to this, somewhat bracing, assertion: "hence, of human parents of different races, half-breed". (Poddar, Patke \& Jensen, 2008, p. 550). And it is defined by Webster in 1828, as "mongrel or mule; an animal or plant, produced from mixture of two species"(as cited in Young, 2005, p. 5). Mary Louise Pratt argues that "the colonizer- as much as the colonized- is implicated in the transcultural dynamics of the colonial encounter" (Gandhi 1998, p. 131). For Bhabha, hybridity is a mediator between colonial domination and its resistance. (Poddar et al., 2008, p. 552). In Bhabha's view, there is an interaction between colonizer and colonized which does not just effect the colonized, but the colonizer as well. In earlier writings on Colonialism, such an interaction had often been denied. As Bertens notes,

Aime Cesaire, for instance, claimed in his 1955 Discourse on Colonialism that between colonizer and colonized there is no human contact, but relations of domination and submission which turn the colonizing man into a classroom monitor, an army sergeant, a prison guard, a slave driver, and the indigenous man into an instrument of production. British and French accounts of colonial life had standardly presented a wholly different, and benign, view of colonialism, but had seen as little interaction between colonizer and colonized as Cesaire. The colonizers remained their civilized and disciplined European selves even in the most trying circumstances. (2002, p. 206)

For Bhabha, the encounter of colonizer and colonized always affects both. More specifically, for Bhabha, the colonizer cannot escape a complex and paradoxical relationship with the colonized (Bertens, 2002, p. 207). Defining hybridity, Bhabha in his The Location of Culture (1994) says:

Hybridity is the sign of the productivity of colonial power, its shifting forces and fixities; it is the name for the strategic reversal of the process of domination through disavowal (that is, the production of discriminatory identities that secure the 'pure' and original identity of authority). Hybridity is the revaluation of the assumption of colonial identity through the repetition of discriminatory identity effects. It displays the necessary deformation and displacement of all sites of discrimination and domination. (p. 160)

Bhabha assumes that " in the colonial encounter, it is not just the colonized who are subjected to Western ways, the colonizers too are transformed, while the colonized deploy borrowed forms to tell their own, distinct narratives which unsettle and subvert the cultural authority of the colonizers" (Werbner 2001, p. 136). Paul Jay's description of cultural hybridity is also notable:

[...] the necessity of cultural conversion led to the creation of indigenous subjects who, forced to absorb Western cultural practices and religious beliefs, subtly transformed them to accord with the vestiges of their own. Colonizing forces, while seeking to wipe out indigenous or slave cultures, sometimes missed but often tolerated and even exploited this phenomenon, since it served to ease the transformation of both indigenous peoples and transported slaves into Western subjects. The result was a mixed one for both colonizer and colonized. For the colonizer, this kind of syncretism helped smooth the cultural conquest of indigenous and slave populations, but it at the same time gave some measure of control over that culture to these populations, a control which often transformed the colonizer's own culture. This kind of syncretism had mixed results for the colonized as well, who found their cultures virtually wiped out but were nevertheless able to incorporate vestiges of it into the one forced upon them. (Jay 2009, p 178)

This essay tries to shed light on the modality of the colonial experience also affecting the colonizer in the case of two novels addressing America's colonial history. Both of these late novels of Cather are based on the lives of European colonists. Death Comes for the Archbishop deals with two French Catholic missionary priests, the bishop Jean Marie Latour and his vicar Joseph Vaillant, who were sent to an unknown diocese in New Mexico in order to make the inhabitants 'civilized' and Shadows on the Rock is based on the lives of Euclide Auclair, who works in an apothecary, and his daughter Cecile, French colonists in Quebec. In both novels the colonists came to the colonized region with their stereotypical views, traditionally held by colonizers. As Tyson explains:

Colonialist ideology, often referred to as colonialist discourse to mark its relationship to the language in which colonialist thinking was expressed, was based on the colonizers' assumption of their own superiority, which they contrasted with the alleged inferiority of native (indigenous) peoples, the original inhabitants of lands they invaded. The colonizers believed that only their own AngloEuropean culture was civilized, sophisticated or as postcolonial critics put it, metropolitan. Therefore, native peoples were defined as savage, backward, and undeveloped. Because their technology was more highly advanced, the colonizers believed that their whole culture was more highly advanced, and they ignored or swept aside the religions, customs and codes of behavior of the peoples they subjugated. So the colonizers saw themselves at the centre of the world, the colonized were at the margins. (2006, p. 419)

Indians are perceived more or less as cannibal barbarians in Shadows (Murphy, 1995, p. 2). They imaged as no less savage in Death either. It starts with the gathering of four cardinals in which Father Ferrand urges that a missionary priest be sent to New Mexico. One cardinal in response to Ferrand's description of life in New Mexico remarks, "I 
suppose it is no worse than a life among the Hurons. My knowledge of your country is chiefly drawn from the romances of Fenimore Cooper, which I read in English with great pleasure." (Cather, 1927, p. 7). The colonizers' opinions of the colonized nations are restricted just to their readings and what they have heard from their ancestors. "The desert down there has a peculiar horror; I do not mean thirst, nor Indian massacres, which are frequent."(Cather, 1927, p. 5). The colonized native inhabitants were called savages, mostly because of their traditions. The term savage is only used by Western societies in order to establish the Western ideals as the norm and simultaneously define what is not western as primitive and inferior. From the perspective of colonizers, the missionary priest is supposed to "deal with savagery and ignorance, with dissolute priests and political intrigue. He must be a man to whom order is necessary as dear as life" (Cather, 1927, p. 5). Homi Bhabha in his The Location of Culture notes that, "The objective of colonial discourse is to construe the colonized as a population of degenerate types on the basis of racial origin, in order to justify conquest and to establish systems of administration and instruction."(1994, p. 70). Colonizers, in these novels, see their mission as duty "to conquer the continent and impose her superior government, culture and way of life on all of its inhabitants" (Tellefsen, 2000, p. 8). They believe that "America must cleanse the continent for its own good" (Tellefsen, 2000, p. 8). On Cather's novel, Tellefsen further observes that: "The narrative opens in the year 1848, the year of American conquest of New Mexico, and thus it appears obvious that Death was written to support retroactively that duty"( 2000, p. 8). Indeed, Father Latour, himself, writes to his sister,

I mean to help the officers at their task here. I can assist them more than they realize. The Church can do more than the Fort to make these poor Mexicans 'good Americans.' And it is for the people's good; there is no other way in which they can better their condition. (Cather, 1927, p. 23)

Colonizers in these novels, especially in Death, consider themselves as martyrs; as the characteristic of the would-besent missionary priest is told that: "He will be called upon for every sacrifice, quite possibly for martyrdom"(Cather, 1927, p. 23). They even compare themselves with Jesus Christ,

[...] of our entire Lord's physical sufferings, only one, 'I thirst', rose to His lips. Empowered by long training, the young priest blotted himself out of his consciousness and mediated upon the anguish of his Lord. The Passion of Jesus became for him the only reality; the need of his own body was but a part of that conception" (Cather, 1927, p. 12).

To some the use of the omniscient point of view and the comparisons between the colonizers and the colonized, intimates that the narrative tips toward the colonizers. Cather depicts both novels from the colonizers' view point; in Death, from the views of Father Latour and Father Vaillant, and in Shadows through the lens of the Auclairs. Before appointing any priest for the diocese in Death, one of the bishops says that "it would be a great misfortune if a native priest were appointed; they have never done well in that field" (Cather, 1927, p. 5). This shows that even the religious colonizers have the superior view toward their colonized native compeers. One of these comparisons is made between Father Latour and his native compeer, Father Martinez. Cather's portrayal of a Roman Catholic Archbishop, Father Latour, appeared so positive in comparison with the natives that many reviewers assumed that the author must be Roman Catholic. (Bohlke, 1977, p. 1). Cather's siding with colonizers caused overlooking the real historical facts regarding these characters. Cather has often been criticized for fictionalizing the actual priest, Antonio Jose Martinez, in order to make him into an almost completely negative character: "in her simplification of the past, she is causing the alienation of a set of readers who recognize more of historical artifact than she has intended". (DeFrancesco, 2008, p. 3). Cather has also been accused of depicting Martinez negatively in order to highlight the positive characteristics of Bishop Latour, who is clearly meant to be an admirable man. Cather's alleged siding with the colonizers is said to be apparent in her description of them in which every positive characteristic is ascribed to them. However, Cather could be said to have as her main objective an attempt to demonstrate the colonialist mindset. As another example, Cather portrays Father Latour, at his entrance among natives, as being superior and distinguished to those natives, "Every thing showed him to be a man of gentle birth - brave, sensitive, courteous. His manners, even when he was alone in the desert, were distinguished" (Cather, 1927, p. 12). However, Cather could be said to have, as her main objective, an attempt to demonstrate the colonialist mindset.

The French colony in Shadows is described as cut off from the 'world.' After the departure of ships from Quebec's coast, "for eight months, the French colony on this rock in the North would be entirely cut off from Europe, from the world" (Cather, 1931, p. 5). To portray the vigor of colonizers' tradition, we are told that even Blinker, himself a torturer, is afraid of Indians and the colonized natives,

This Blinker had never had a gun in his hands. He had such a horror of the forest that he would not even go into the near-by woods to help fell trees for firewood, and his fear of Indians was one of the bywords of Mountain Hill.[...] Blinker protested he had been warned in a dream that he would be taken prisoner and tortured by the Indians.( Cather, 1931, p. 12)

Similarly, Euclide Auclair, as a missionary colonizer, does not even consider Indians as fully human. Talking with Mother Juschereau about native remedies, he says:

Dear Mother Juschereau, the idea of such treatment is repugnant to me. We are not barbarians, after all."

"But they are flesh and blood; how is it they recover?"

$[\ldots]$ 
"Auclair explained his reasons for believing that the savages were much less sensitive to pain than

Europeans. (Cather, 1931, p. 24)

This view of the natives and their land, which the colonizers call Quebec, is nowhere better expressed than by Count Frontenac:

Nothing is more unpopular at Court than the geography of New France. They like to think of Quebec as isolated, French, and Catholic. The rest of the continent is a wilderness, and they prefer to disregard it. Any advance to the westward costs money - and Quebec has already cost them enough. (Cather, 1931, p. 150) (Emphasis Added)

On arriving at the colony, missionary colonists attempt to establish their own lifestyle without considering the native one. They want to create a 'New France' out of what they consider a wilderness. In Death, the priests try to decorate their house like a French one. Father Latour even builds a garden and in an attempt to make it the same as the one he had in his country, fills with European vegetables and fruits. In Shadows, Madame Aulair tries her best to make her house look like the one they had in their mother country:

Madame Auclair had brought her household goods, without which she could not imagine life at all, and the salon behind the shop was very much like their old salon in Paris. There was the same wellworn carpet, made at Lyon, the walnut dining-table, the two large arm-chairs and high-backed sofa upholstered in copper-red cotton-velvet, the long window-curtains of similar velvet lined with brown. The same candelabra and china shepherd boy sat on the mantel, the same color prints of pastoral scenes hung on the walls. Madame had brought out to Canada the fine store of linen that had been her marriage portion, her feather beds and coverlids and down pillows. As long as she lived, she tried to make the new life as much as possible like the old. (Cather, 1931, p. 16)

After she becomes sure that she would never be well enough to return to France, her chief care is to train her little daughter so that she would be able to carry on this life and this order after she is gone. Even on her deathbed, she tells her daughter, Cecile:

[...] you will perhaps find it fatiguing to do all these things alone, over and over. But in time you will come to love your duties, as I do. You will see that your father's whole happiness depends on order and regularity, and you will come to feel a pride in it. Without order our lives would be disgusting, like those of the poor savages. At home, in France, we have learned to do all these things in the best way, and we are conscientious, and that is why we are called the most civilized people in Europe and other nations envy us. (Cather, 1931, p. 17)

The colonialist mentality colored with Christian humanitarianism here - civilizing as a mission, as a moral duty - mostly hinges on the trope of 'order.' To the missionaries order is the chief feature that separates them from the 'degenerate' natives. Cecile as the French-born colonist tries to recreate a European culture in the wilderness, "the colonists liked to drop in at Auclair's house upon the slightest pretext; the interior of the Auclair's shop was like home to the French born", "life would go on almost unchanged in this room" because Madame Auclair teaches Cecile "the sense of our way", "a feeling that had come down to her through so many centuries and that she had brought with her across the wastes of obliterating, brutal ocean" (Cather, 1931, p. 16-18). Euclide Auclair regards his dinner "as the thing that kept him a civilized man, a French man" (Cather, 1931, p. 12). He also tries to keep his twelve years old daughter, Cecile, from mingling with the natives and attempts to bring her up by the French manners, "She read aloud to him, the fables of La Fontaine or his favorite Plutarch, and he corrected her accent so that she would not be ashamed when she returned home to the guardianship of that intelligent and exacting Aunt Clothilde" (Cather, 1931, p. 13). Likewise, Father Latour, at the beginning of Death, is described as a man "to whom order is necessary - as dear as life" (Cather, 1927, p. 6). In brief, colonizers want to fashion themselves as civilized and ordered humans living among those they label savages.

Both novels are centrally concerned with what colonizers think about the colonized natives. There are, however, some instances of what the natives think about the colonizers. Also the natives, in both novels, act biasedly according to their instinctual hatred of the colonizer. In Death the native Mexican priests refuse to recognize the new European priests' authority. Jose, one of the natives, says: "They say at Albuquerque that now we are all Americans, but that is not true, Padre. I will never be an American. They are infidels" (Cather, 1927, p. 17). He then adds: "They destroyed our churches when they were fighting us, and stabled their horses in them. And now they will take our religion away from us. We want our own ways and our religion" (Cather, 1927, p. 17). In her description, Cather points out that "both the priest and people were hostile to Americans and jealous of interference. Any Europeans [...] was regarded as a gringo" (Cather, 1927, p. 84). At issue here is the identity of the natives and how they even consider themselves as independent of the Catholic church (though they are at least nominally Catholics themselves), let alone the Americans, the new colonizers. These Christianized natives could be said to have a hybrid identity. And yet, they are proud of and protective of it. Thus the native priest continues:

We have a living Church here, not a dead arm of the European Church. Our religion grew out of the soil, and has its own roots. We pay a filial respect to the person of the Holy Father, but Rome has no authority here. We do not require aid from the Propaganda, and we resent its interference. The Church of the Franciscan Fathers planted here was cut off; this is the second growth, and is indigenous. Our people are the most devout left in the world. If you blast their faith by European formalities, they will become infidels and profligates. (Cather, 1927, p.88) 
Cather puts on display in these novels the complexities of colonialism, its assumptions, its ruses and justifications, the dialectic of colonizer/colonized relationship, its contradictions and, no less importantly, resistance to it. For instance, the French bishop is advised:

You are a young man my Bishop [...] and you know nothing about Indians or Mexicans. If you try to introduce European civilization here and change our old ways, to interfere with the secret dances of the Indians, let us say, or abolish the bloody rites of the Penitentes, I foretell an early death for you. I advise you to study our native traditions before you begin your reforms. (Cather, 1927, p. 89)

Yet, by and by, the missionaries' eyes are opened to the differences of their own culture with that of the natives. These newly perceived differences will shake the colonizers' fixed opinion of the natives and also themselves. One of the matters which missionaries in both novels encounter, through their interaction with the colonized, is 'miracles'. Father Latour and Eclide Auclair look skeptically at the extravagance of 'miracles' which the natives believe can happen at every moment. Cecile, who is a French-born colonist, is brought up among the natives. Her views regarding miracles differ from her father's and from those of her father's native predecessor. For her "all the miracles that had happened there $[\ldots]$ took on the splendor of legend"(Cather, 1931, p. 61). In a sense, Cecile plays the role of mediator between these two opposed stances.

European missionaries believe themselves to be civilized and ordered and the colonized natives as savage, brutal and degenerate. One of the elements which shake missionaries' self-assurance and their rigid opinions is the other Europeans or Americans in the novels who act contrary to these fixities. One of them is an American man, Buck Scales, whom the priests Father Latour and Father Vaillant meet on the road to Mora. This man, civilized in the colonizers' definition, is a murderer who plans to kill the priests as well as four travelers and his own three children. But the priests are saved by the help of Scales' Mexican wife, Magdalena. In other words, they are saved by a 'savage' from a 'civilized' person. In Shadows, Blinker, formerly a torturer at the king's prison, plays the role of shaking the colonizers' fixed opinions.

Missionary colonists, after realizing the differences in their beliefs and culture with those of natives, contrary to their predecessor's traditional opinions, do not take any coercive action toward them. Instead, they try to accept those differences and respect them. Their new attitude towards the colonized differs considerably from the dictated fixed stance of superiority and domination. For instance, in Death when Fatour Latour is travelling with Jacinto, he does not allow himself to preach to Jacinto or even to disrupt his thoughts.

The Bishop seldom questioned Jacinto about his thoughts or beliefs. He didn't think it polite, and he believed it to be useless. There was no way in which he could transfer his own memories of European civilization into the Indian mind, and he was quite willing to believe that behind Jacinto there was a long tradition, a story of experience, which no language could translate to him. (Cather, 1927, p. 55)

Breaking through the entrenched, age-old prejudices, Father Latour comes to have a new understanding of native character. One of these natives is Eusabio, whom Father Latour befriends.

Travelling with Eusabio was like travelling with the landscape made human. He accepted chance and weather as the country did, with a sort of grave enjoyment. He talked little, ate little, slept anywhere, preserved a countenance open and warm, and like Jacinto he had unfailing good manners. The Bishop was rather surprised that he stopped so often by the way to gather flowers. [...] Father Latour judged that, just as it was the white man's way to assert himself in any landscape, to change it, make it over a little (at least to leave some mark of memorial of his sojourn), it was the Indian's way to pass through a country without disturbing anything; to pass and leave no trace, like fish through the water, or birds through the air. It was the Indian manner to vanish into the landscape, not to stand out against it. (Cather, 1927, p. 138)

Now, after many years the two priests in Death reach their old age. Their pre-established colonialistic fixities have changed and they have come into an acceptance of the endurance of the natives' traditions and culture. They do not go back to their mother country at the end of their mission and stay at their diocese. In a sense they come to accept the inevitable hybridity of cultural identity. Though they have not 'gone native', they have travelled enough away from their dogmas to be content to live out their lives with the natives. Or maybe they have travelled even farther. The notion of 'hybridity' is nowhere more manifestly referred to than in the following passage, where Father Vaillant acknowledges that:

[...] down there it is work for the heart, for a particular sympathy, and none of our new priests understand those poor natures as I do. I have almost become a Mexican! I have learned to like chili colorado and mutton fat. Their foolish ways no longer offend me, their very faults are dear to me. I am THEIR MAN! (Cather, 1927, p. 123)(Emphasis Added)

He "has almost become a Mexican." In Shadows, this process of 'hybridization' is even more explicit. Cecile, who is born in France, knows herself to be more Canadian than French. She marries -- in Quebec -- with a Canadian. Cecile's marriage further confirms her identity as a Canadian. As a child, Pierre had told her "You and I are Canadians, monkey. We were born here" (Cather, 1931, p.110). She had been disturbed by the thought of leaving Canada to return to France, and now she has become the mother of "the Canadians of the future,- - the true Canadians" (Cather, 1931, p. 175). Cecile plays a unique role as a moderating force between the Canadian-born and the French-born in this transformation, as what Bhabha called 'in-betweenness', a person who stands between two cultures. It takes fifteen years, but at the end of the book, Eclide Auclair, has finally become 'Canadian' too, content in his family, secure in his 
home, rooted in his own new country and the tradition from which that country began, "[...] indeed fortunate to spend his old age here where nothing changed; to watch his grandsons grow up in a country where the death of the King, the probable evils of a long regency, would never touch them"(Cather, 1931, p. 175).

\section{Conclusion}

In this essay an attempt was made to look at Willa Cather's two later novels, Death Comes for the Archbishop and Shadows on the Rock, from a perspective other than the common historical one. We argue that what makes these two novels of particular significance is the way they address the modality of colonizer/colonized relationship at crucial moments in the history of colonialism. The complications of colonialism, its assumptions, justifications, contradictions as well as resistance to it are all touched upon in these two related works. As such, the novels seminally register cultural change, one which, it is argued, could be fruitfully explained in terms of Homi Bhabha's theory of hybridity. The Western myth that its presence overseas greatly affects the natives, as it is meant to, but the Western colonizers could/are not affected by the cultures they encounter is debunked in the novels as they dramatize how those who come to change are themselves subject to change too.

\section{References}

Bertens, H. (2002). Literary Theory: The Basics. New York: Routledge.

Bhabha, H. K. (1994). The Location of Culture. New York: Routledge.

Bohlke, L. B. (1977). On Cather's Death Comes for the Archbishop. Willa Cather Pioneer Memorial Newsletter Vol. 21, No.1, 1-2.

Danker, K. (2000). The influence of Willa Cather's French- Canadian Neighbors in Nebraskain Death Comes for the Archbishop and Shadows on the Rock. Great Plains Quarterly. Vol. 20, No. 1, 35-54. Retrieved from http://www.jstor.org/stable/23533054

Cather, W. (1927). Death Comes for the Archbishop. New York: Knopf.

Cather, W. (1931). Shadows on the Rock. New York: Knopf.

Cather, W. (1949). On Writing: Critical Studies on Writing as an Art. Lincoln: University of Nebraska.

Daiches, D. (1951). Willa Cather: A Critical Introduction. New York: Cornell University Press.

DeFrancesco, M. (2008). The Mobile Sections of Death Comes for the Archbishop. Willa Cather, Newsteller and Review Vol.52, No. 1, 3-7.

Gandhi, L.(1998). Postcolonial Theory: A Critical Introduction. New York: Columbia University

Jay, P. (2009). Hybridity, Identity and Cultural Commerce in Claude Mckay‘s _Banana Bottom. Callaloo. Retreived from http://www.jstor.org/stable/3299961

Murphy, J. J. (1995). Shadows on the Rock, Maria Chapdelaine, and the Old Nationalism. Willa Cather Pioneer Memorial Newsletter Vol.39, No.1, 1-6.

Park, H. (2006). A Quest for Memory in Willa Cather's Death Comes for the Archbishop. Willa Cather, Newsteller and Review Vol.50, No.2, 13-17.

Poddar, P., Patke, R. S. \& Jensen, L. (2008). A Historical Companion to Postcolonial Literatures. Edinburgh: Edinburgh University Press.

Reynolds, G. (2005). Willa Cather as Icon. Cather Studies. Vol.7. Lincoln: University of Nebraska.

Tellefsen, B. (2000). Reading Cather Read America in Death Comes for the Archbishop. Willa Cather, Newsteller and Review Vol.44, No. 1, 7-10.

Tyson, L. (2006). Critical Theory Today. New York: Routledge.

Werbner, P. (2009). The Limits of Cultural Hybridity: On Ritual Monsters, Poetic Licence. The Journal of the Royal Anthropological Institute. Retrieved from http://www.jstor.org/stable/2660840

Young, R. J. (2005). Colonial Desire: Hybridity in Theory, Culture and Race. New York: Routledge. 